ZOOLOGIA 27 (4): 541-553, August, 2010

doi: $10.1590 /$ S1984-46702010000400006

\title{
Occurrence and distribution of larval lanternfish (Myctophidae) from the southwest Atlantic Ocean
}

\author{
Márcia S. de Castro'; William J. Richards² \& Ana Cristina T. Bonecker¹
}

\author{
${ }^{1}$ Departamento de Zoologia, Instituto de Biologia, Universidade Federal do Rio de Janeiro. CCS, Bloco A, Ilha do Fundão, \\ 21941-590 Rio de Janeiro, RJ, Brazil.E-mail: mscastro@biologia.ufrj.br; ana@biologia.ufrj.br \\ ${ }^{2}$ NOAA Fisheries, Southeast Fisheries Science Center. 75 Virginia Beach Drive, Miami, FL 33149, USA. \\ E-mail: bill.richards@noaa.gov
}

\begin{abstract}
This study analyzes the occurrence and distribution of lanternfish (Myctophidae) larvae along the Brazilian coast $\left(12-22^{\circ} \mathrm{S}\right)$ between $200 \mathrm{~m}$ and the surface. Three cruises were conducted during the spring/1998, winter/1999 and autumn/2000. A total of 3,394 lanternfish larvae were identified representing 27 species and Lepidophanes guentheri (Goode \& Bean, 1896) was the most abundant. Most of the identified taxa were in the postflexion stage. Myctophid larvae were more numerous during the winter. Most taxa were distributed widely from $12-22^{\circ} \mathrm{S}$, including some seamounts, and occurred mainly outside the $1,000 \mathrm{~m}$ isobath. Although there was no difference in the myctophid community among the coastal, oceanic and seamount regions it was significantly different during the three seasons. During the spring and autumn Hygophum reinhardtii (Lütken, 1892) was the discriminating species while in the winter there were more L. guentheri.
\end{abstract}

KEY WORDS. Brazilian coast; larval mesopelagic fish; Myctophidae; spatial variation; tropical region.

Myctophids are mid-water fishes with laterally compressed bodies, measuring from 3-35 cm (Moser \& Анцsтrom 1996, Moser \& Watson 2006), and have a circumglobal distribution (GARTNER et al. 1989). Myctophidae larvae are common in offshore samples, representing approximately $50 \%$ of all larvae collected in oceanic studies (Moser \& AHLstrom 1974).

Myctophidae contains 32 genera and 235 species (NELSON 2006). Adults have been fairly well studied and numerous species have been described (Nafpaktitis et al. 1977, Hulley 1981, 1984, 1986, 1994, BeCKer 1983, Gartner et al. 1987).

Based on eye shape, lanternfish larvae can be separated into two groups. Myctophinae includes larvae with narrow, elliptical eyes while the Lampanyctinae is comprised of individuals with round or nearly round eyes (Moser \& AнLSTrom 1970, 1974, 1996). The first subfamily comprises about 14 genera and the later has about 18 genera (NeLSON 2006).

Some myctophid species undergo vertical migration and this behavior suggests that lanternfishes play an important role in transferring energy from the upper to the deeper layers as they feed in the surface and defecate near the bottom (ANGeI 2003, Conley \& Hopkins 2004). They are also considered a possible source of human exploitation as they are preyed upon by fishes with high commercial value such as salmons and tunas (Nafpaktitis et al. 1977, Moser \& Ahlstrom 1970, 1996, Costa 2004, KARAKULAK et al. 2009) and have been commercially fished in the Southern Ocean (Coluns et al. 2008). Although mesopelagic fishes are not usually exploited they are potentially useful as indicator species as their distribution are often related to physical, chemi- cal and biological characteristics of water masses (Hulley 1992) and are sensitive to environmental changes (НsieH et al. 2005).

Although there are several studies that describe the early life history of myctophid fishes (e.g. Nafpaktiтis 1975, Ozawa 1986, Moser et al. 1984, Zelck et al. 1993, Olivar \& Palomera 1994, Moser \& Ahlstrom 1996, Moser \& Watson 2006), some species have undescribed larvae. In Brazil, there have been few studies of myctophid larvae and most of them identified individuals only to the family level (BONECKer et al. 1993, EKAU \& Matsuura 1996, Ekau et al. 1999, Nogueira et al. 1999, Nonaka et al. 2000) and data on the distribution of myctophid species are scarce. Therefore, this study reports on a series of larval myctophid collections from Brazil, improving identifications at generic and species levels. It also relates species occurrence with salinity, temperature, seasonal and spatial variation.

\section{MATERIAL AND METHODS}

Our study material is part of the Brazilian Program called Avaliação do Potencial Sustentável de Recursos Vivos na Zona Econômica Exclusiva - REVIZEE. The study area extends along the Brazilian coast between $12^{\circ} \mathrm{S}$ and $22^{\circ} \mathrm{S}$. The continental shelf between $16^{\circ} \mathrm{S}$ and $23^{\circ} \mathrm{S}$ has an irregular profile. In the north, the continental shelf is $55 \mathrm{~km}$ wide. Near the Royal Charlotte Bank it is $110 \mathrm{~km}$ wide, reducing to $45 \mathrm{~km}$ between the banks; near the Abrolhos Bank the continental shelf enlarges again to 190 km (CASTRo \& Miranda 1998) (Fig. 1). The presence of Abrolhos Bank and the seamounts of Vitória-Trindade ridge influence the 
downward flux of the Brazil Current, generating eddies, meanders and upwelling in this region (EKaU \& Matsuura 1996). The Brazil Current transports the nutrient poor Tropical Water mass southward, resulting in oligotrophic conditions in this area (GAETA et al. 1999). Water masses present in the study area are classified according to EMILSON $(1959,1961)$ and Silveira et al. (2000) as follows: Shelf Water (SW) $-\mathrm{T}>20^{\circ} \mathrm{C}$ and $35<\mathrm{S}<36$; Tropical
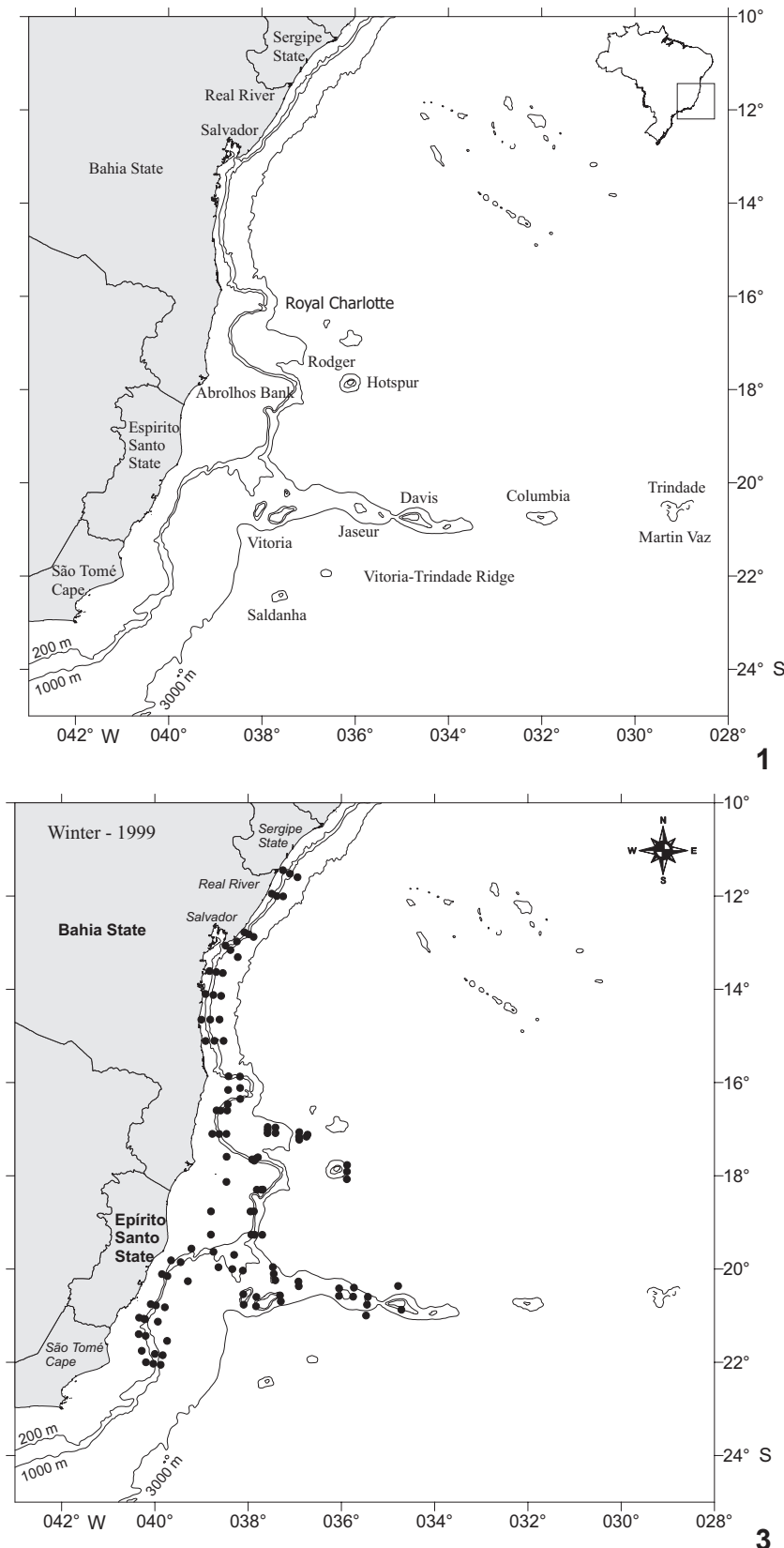

Figures 1-4. Study area indicating the main geographical features (1) and sampling stations during the spring (2), winter (3) and autumn (4) cruises.
Water (TW) $-\mathrm{T}>20^{\circ} \mathrm{C}$ and $\mathrm{S}>36$; South Atlantic Central Water (SACW) $-6^{\circ} \mathrm{C}<\mathrm{T}<20^{\circ} \mathrm{C}$ and $34.6<\mathrm{S}<36$.

Plankton was collected during three oceanographic cruises during spring (October-December of 1998), winter (MayJune of 1999) and autumn (March-May of 2000). A total of 658 samples were collected during the day and night, encompassing 329 stations (Figs 1-4). Sampling methodology was the same
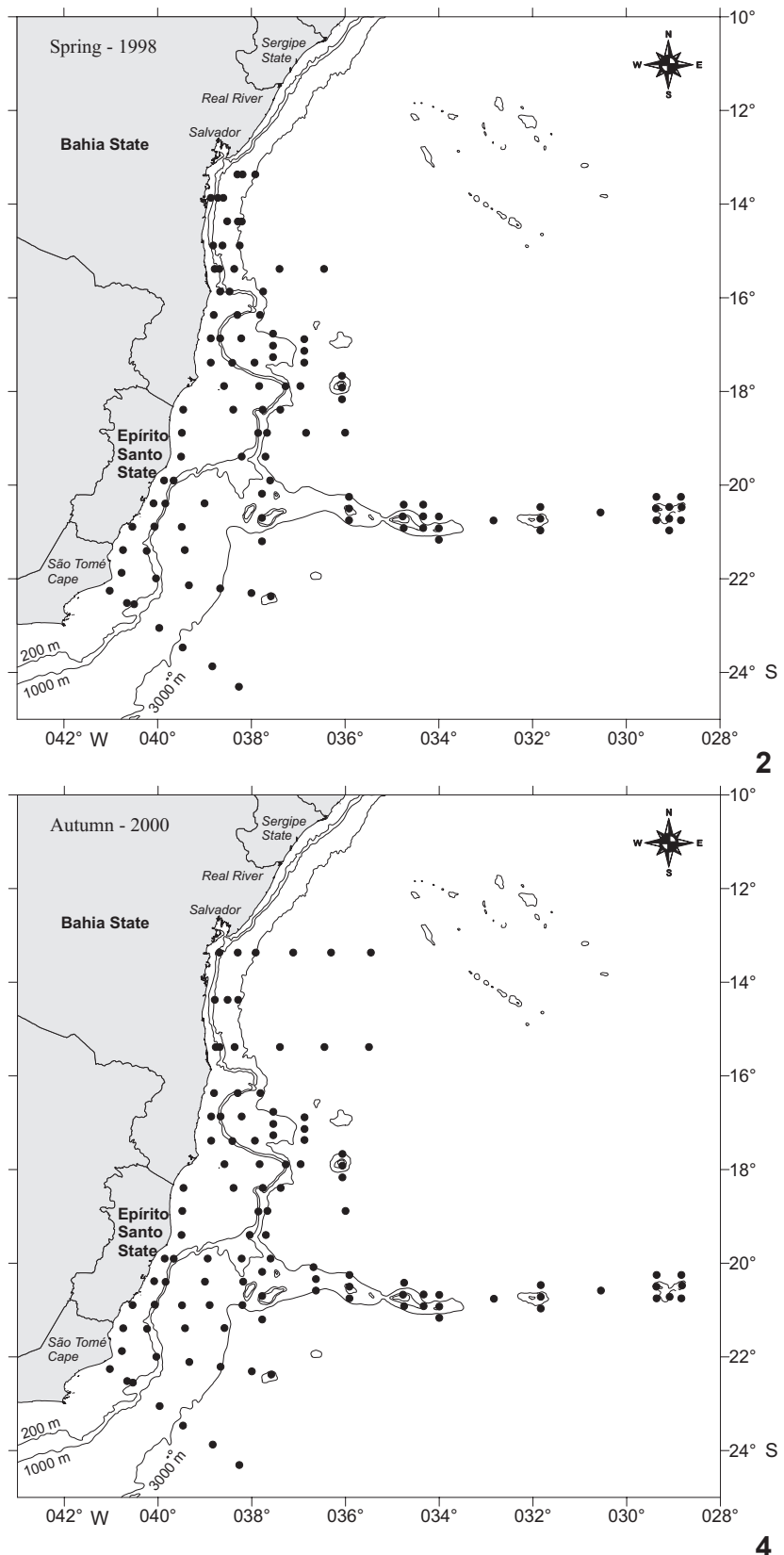

ZOOLOGIA 27 (4): 541-553, August, 2010 
for all three cruises. Oblique bongo net hauls using 330 and $500 \mu \mathrm{m}$ mesh aperture sizes were conducted from the maximum depth of $200 \mathrm{~m}$ to the surface at each station. At shallower stations the net was deployed to near the bottom and then retrieved to the surface. Two digital flowmeters (General Oceanics) were used to estimate the water volume filtered and samples were preserved in $4 \%$ buffered formalin. The average volumes of water filtered were $381.7 \mathrm{~m}^{3}$ during the spring, 458.6 $\mathrm{m}^{3}$ in the winter and $495.0 \mathrm{~m}^{3}$ in the autumn. Temperature and salinity data were obtained using a CTD SeaBird-SBE19-03 Seacat Profiler, at five depths: surface, $20 \mathrm{~m}, 50 \mathrm{~m}, 100 \mathrm{~m}$ and $200 \mathrm{~m}$.

All myctophid larvae were sorted from the samples and identified based on published descriptions (NAFPakTitis et al. 1977, MOSER \& WATSON 2006). The smallest and largest individuals of each species were measured (standard length - SL) with a micrometer ruler (precision of $0.1 \mathrm{~mm}$ ). Larvae were staged according to notochord flexion into preflexion, flexion and postflexion stages (Ahlstrom et al. 1976). Specimens with all the fin rays formed were staged as postlarvae. Identified specimens were deposited in the larval fish collection of the Zooplankton and Ichthyoplankton Integrated Laboratory of Federal University of Rio de Janeiro - Brazil (DZUFRJ).

Only abundances of larvae collected with $330 \mu \mathrm{m}$ mesh were used for all statistical analyses. Standardized density data, number of larvae under $10 \mathrm{~m}^{-2}$ of sea surface, were transformed to $\log (\mathrm{x}+1)$, to ensure that each species contributed evenly to the analyses. The same matrix was used in all analyses and was composed of 14 species and 182 samples. Species that occurred in less than five samples in all cruises were excluded from the matrix to avoid interference from rare taxa. Only specimens identified to species level were used in the analyses except for Lampanyctus sp. and Lampadena sp. which represented unique species. The results were considered significant at significance level $<5 \%$.

Sampling stations were classified according to seasonality (spring, winter, autumn) and with local depth (shelf, oceanic, seamount). Analyses of similarities (ANOSIM) were used to de- termine whether differences among the three periods of the year and among the three areas were significant. Similarity percentage analyses (SIMPER) were used, when a significant difference was observed, to identify the species that contributes greatest to each grouping. Species that accounted for more than $90 \%$ were considered key species. All multivariate analyses were done using the PRIMER programme (CLARKE \& WARWICK 1994).

Canonical correspondence analysis (CCA), using the PCORD version 4 (Mc Cune \& MefFord 1999), was used to analyze the relationship between some myctophid species collected during the three cruises and environmental parameters (temperature and salinity at $20 \mathrm{~m}$ depth and local depth). The Monte Carlo method, with 99 permutations (MC CunE \& MEFFord 1999), was used to verify the statistical significance of the environmental data selected.

\section{RESULTS}

\section{Oceanographic conditions}

Water temperature (surface to $200 \mathrm{~m}$ ) varied from 13.6 to $28.1^{\circ} \mathrm{C}$ during spring, from 14.3 to $28.6^{\circ} \mathrm{C}$ in autumn and from 14.4 to $27.3^{\circ} \mathrm{C}$ during winter (Tab. I). Salinity did not vary greatly during the three periods and in general ranged from 35.2 to 37.9 (Tab. I).

Low temperatures at $20 \mathrm{~m}, 100 \mathrm{~m}$ and $200 \mathrm{~m}$ occurred near Vitória and São Tomé Cape, during the three cruises.

Salinity values at $20 \mathrm{~m}$ depth were lower near São Tomé Cape and higher north of Abrolhos ( $\left.18^{\circ} \mathrm{S}\right)$. At 100 and $200 \mathrm{~m}$ this difference was not as evident as at $20 \mathrm{~m}$ depth. Salinity characteristics of SACW were recorded near São Tomé Cape at 100 (spring cruise) and $200 \mathrm{~m}$ depths.

According to temperature/salinity (T/S) diagrams for the three cruises (Figs 5-7), two water masses were dominant in the study area: Tropical Water and South Atlantic Central Water. Tropical Water was generally found from the surface to 100 $\mathrm{m}$ and SACW at depths below $200 \mathrm{~m}$. However, at some sampling stations TW was found below $100 \mathrm{~m}$ and SACW was de-

Table I. Minimum (Min) and maximum (Max) values of temperature $\left({ }^{\circ} \mathrm{C}\right.$ ) and salinity obtained at surface, $20 \mathrm{~m}, 50 \mathrm{~m}, 100 \mathrm{~m}$ and 200 $\mathrm{m}$ depth during spring/1998, autumn/2000 and winter/1999.

\begin{tabular}{|c|c|c|c|c|c|c|c|c|c|c|}
\hline \multirow{3}{*}{ Season } & \multicolumn{10}{|c|}{ Temperature } \\
\hline & \multicolumn{2}{|c|}{ Surface } & \multicolumn{2}{|c|}{$20 \mathrm{~m}$} & \multicolumn{2}{|c|}{$50 \mathrm{~m}$} & \multicolumn{2}{|c|}{$100 \mathrm{~m}$} & \multicolumn{2}{|c|}{$200 \mathrm{~m}$} \\
\hline & Min & Max & Min & Max & Min & Max & Min & Max & Min & Max \\
\hline Spring & 22.2 & 28.1 & 15.6 & 27.4 & 15.5 & 27.2 & 14.7 & 24.8 & 13.6 & 20.5 \\
\hline Autumn & 20.3 & 28.6 & 18.4 & 28.5 & 20.0 & 28.5 & 16.8 & 25.6 & 14.3 & 21.0 \\
\hline \multirow[t]{2}{*}{ Winter } & 22.7 & 27.3 & 22.5 & 27.3 & 20.2 & 27.3 & 18.8 & 26.8 & 14.4 & 19.4 \\
\hline & \multicolumn{10}{|c|}{ Salinity } \\
\hline Spring & 35.8 & 36.2 & 35.7 & 37.9 & 35.6 & 37.5 & 35.4 & 37.3 & 35.3 & 36.8 \\
\hline Autumn & 35.2 & 37.4 & 36.1 & 37.9 & 36.6 & 36.9 & 35.8 & 37.3 & 35.3 & 37.7 \\
\hline Winter & 36.0 & 37.6 & 36.1 & 37.6 & 36.3 & 37.6 & 36.1 & 37.6 & 35.4 & 36.3 \\
\hline
\end{tabular}


tected near $100 \mathrm{~m}$ depth. Besides these two water masses, Shelf Water was also found during the spring and autumn cruises (Figs 5-7), and was also found from the surface to $20 \mathrm{~m}$.
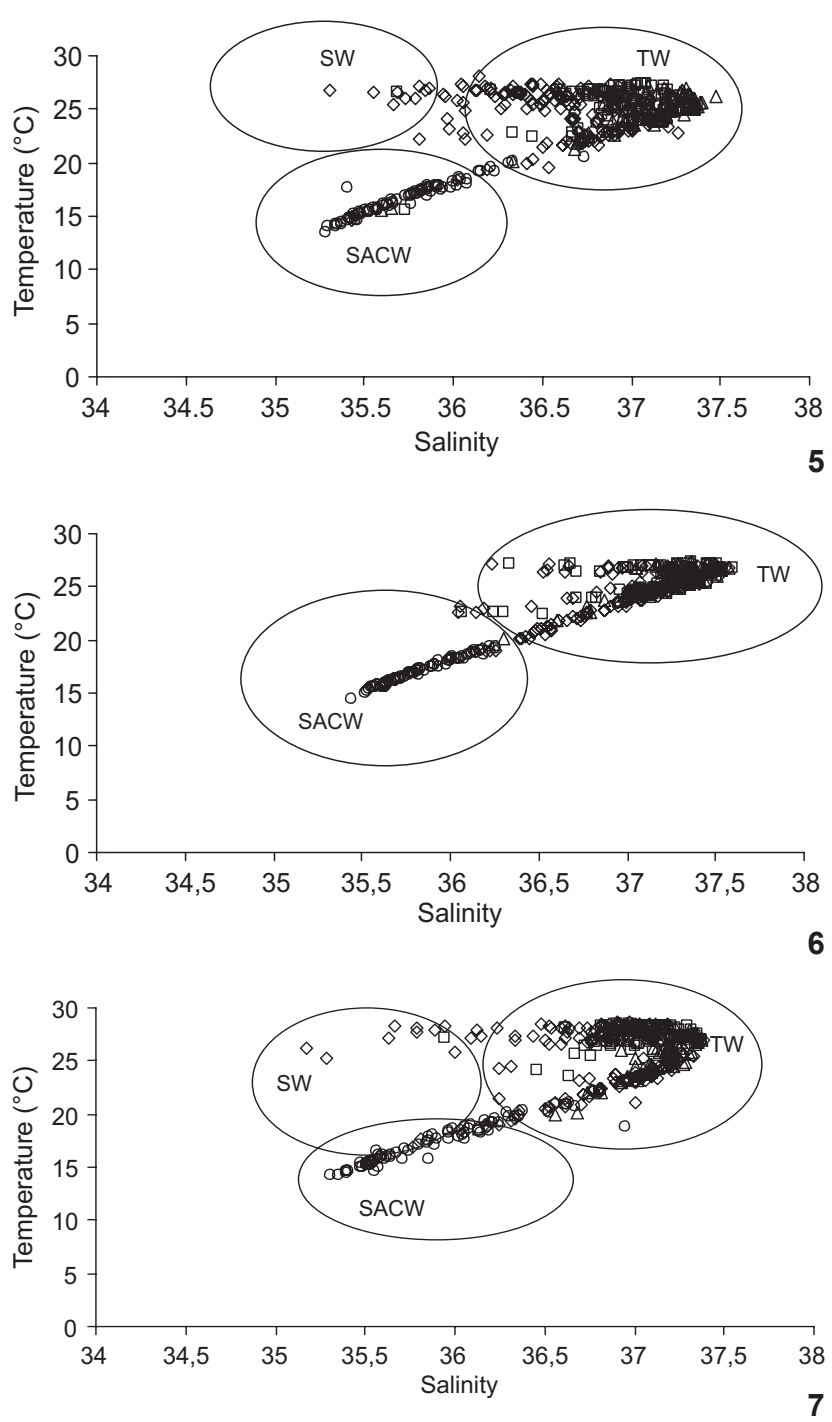

$\diamond$ Surface $\quad \square 20 \mathrm{~m} \quad \Delta 50 \mathrm{~m} \quad \diamond 100 \mathrm{~m} \quad \circ 200 \mathrm{~m}$

Figures 5-7. T/S diagrams for five depths during the spring/1998 (5), winter/1999 (6) and autumn/2000 (7) cruises. (SW) Shelf Water, (TW) Tropical Water, (SACW) South Atlantic Central Water.

\section{Species composition}

A total of 3,394 Myctophidae comprising 12 species of Myctophinae and 15 species of Lampanyctinae were identified (Tab. II).

Among the Myctophinae, Myctophum Rafinesque, 1810 larvae were the most numerous in the study area (Tab. II). Al- though most specimens of Myctophum could only be identified to genus because the pigment patterns were too poorly preserved for definitive identification, four species were positively identified. These four Myctophum species contributed to almost $18.5 \%$ of the total myctophids identified. Hygophum reinhardtii (Lütken, 1892) was also abundant and represented $4.2 \%$ of the total myctophids.

The Lampanyctinae were the most abundant group, dominated by large numbers of Lepidophanes guentheri (Goode $\&$ Bean, 1896) and Diaphus Eigenmann, 1890 that was represented by five species (Tab. II). Most Diaphus were also identified only to genus as were the Myctophum described above. $L$. guentheri accounted for $22 \%$ and five species of Diaphus contributed to $3 \%$ of the total. The species Lampadena sp. represented $4.7 \%$ of the total myctophid identified during the three cruises.

\section{Development stages}

In general, fewer preflexion stage larvae were identified in comparison to the other development stages (Tab. III). In Lampanyctinae most species were more abundant in later development stages, specially the species $L$. guentheri and the Diaphus group. However, for some Myctophinae species (e.g. Benthosema suborbitale (Gilbert, 1913), H. reinhardtii, Myctophum affine (Lütken, 1892), Myctophum nitidulum Garman, 1899, Myctophum selenops Tåning, 1982 and Symbolophurus rufinus (Tåning, 1928) more larvae in the preflexion stage were collected.

\section{Seasonal and spatial variations}

The winter cruise contributed more than $70 \%$ of the total catch and the greatest number of identified taxa, while the autumn cruise represented only $11 \%$ of the total catch (Tab. II). The similarity analysis (ANOSIM) showed a significant difference in myctophid assemblages among spring, winter and autumn $(p=0.001)$. The most representative taxa collected during the three periods are represented in table IV. Similarity percentage analysis (SIMPER) showed little variation on species composition among the three periods (Tab. IV). However, during the spring and autumn $H$. reinhardtii was the discriminating species while in the winter there was greater contribution of L. guentheri (Tab. IV).

The distribution and abundance of the most representative myctophids are shown in figures 8-12. Diaphus spp., $L$. guentheri and Lampadena sp. larvae were more abundant during the winter cruise (Figs 8, 9 and 12) while Myctophum larvae were more representative in the spring cruise (Fig. 10). Hygophum reinhardtii density distributions were similar among the three cruises (Fig. 11). Less representative species were more abundant during the winter cruise, except for Centrobranchus nigroocellatus (Günther, 1873), Hygophum Hygomii (Lütken, 1892), S. rufinus, Ceratoscopelus warmingii (Lütken, 1892) and Lobianchia gemellarii (Cocco, 1838) that were more numerous in the spring (Tab. II). Hygophum taaningi Becker, 1965 and Lampanyctus sp. were collected only during the autumn (Tab. II). 
Table II. Number and percentage (\%) of each Myctophinae and Lampanyctinae species collected during spring/1998 (S), winter/1999 (W) and autumn/2000 (A) cruises conducted along the Brazilian central coast.

\begin{tabular}{|c|c|c|c|c|c|}
\hline Species & $S$ & W & A & Total & $\%$ \\
\hline \multicolumn{6}{|l|}{ Myctophinae } \\
\hline Benthosema suborbitale (Gilbert, 1913) & 12 & 36 & 6 & 54 & 1.59 \\
\hline Centrobranchus nigroocelatus (Günther, 1873) & 3 & & 1 & 4 & 0.12 \\
\hline Diogenichthys atlanticus (Tåning, 1928) & & 2 & & 2 & 0.06 \\
\hline Hygophum spp. & 58 & 16 & 42 & 116 & 3.42 \\
\hline Hygophum hygomii (Lütken, 1892) & 5 & 2 & & 7 & 0.21 \\
\hline Hygophum macrochir (Günther, 1864) & & 2 & & 2 & 0.06 \\
\hline Hygophum reinhardtii (Lütken, 1892) & 30 & 58 & 46 & 134 & 3.95 \\
\hline Hygophum taaningi Bekker, 1965 & & & 2 & 2 & 0.06 \\
\hline Myctophum spp. & 35 & 108 & 31 & 174 & 5.13 \\
\hline Myctophum affine (Lütken, 1892) & 37 & 18 & 3 & 58 & 1.71 \\
\hline Myctophum nitidulum Garman, 1899 & 83 & 62 & 24 & 169 & 4.98 \\
\hline Myctophum obtusirostre Tåning, 1928 & 36 & 52 & 33 & 121 & 3.57 \\
\hline Myctophum selenops Tåning, 1928 & 69 & 33 & 2 & 104 & 3.06 \\
\hline Symbolophorus rufinus (Tåning, 1928) & 11 & 2 & 4 & 17 & 0.50 \\
\hline \multicolumn{6}{|l|}{ Lampanyctinae } \\
\hline Bolinichthys spp. & & 31 & 7 & 38 & 1.12 \\
\hline Bolinichthys photothorax (Parr, 1928) & & 3 & & 3 & 0.09 \\
\hline Ceratoscopelus warmingii (Lütken, 1892) & 10 & 4 & 3 & 17 & 0.50 \\
\hline Diaphus spp. & 176 & 909 & 70 & 1,155 & 34.03 \\
\hline Diaphus anderseni Tåning, 1932 & & 1 & & 1 & 0.03 \\
\hline Diaphus brachycephalus Tåning, 1928 & & 5 & 2 & 7 & 0.21 \\
\hline Diaphus dumerilii (Bleeker, 1856) & & 23 & & 23 & 0.68 \\
\hline Diaphus garmani Gilbert, 1906 & & 6 & 1 & 7 & 0.21 \\
\hline Diaphus splendidus (Brauer, 1904) & & 47 & & 47 & 1.38 \\
\hline Lampadena spp. & 5 & 180 & 37 & 222 & 6.54 \\
\hline Lampadena luminosa (Garman, 1899) & & 3 & & 3 & 0.09 \\
\hline Lampanyctus sp. & 6 & 5 & 7 & 18 & 0.53 \\
\hline Lampanyctus nobilis Tåning, 1928 & & 1 & & 1 & 0.03 \\
\hline Lepidophanes gaussi (Brauer, 1906) & 6 & 39 & 3 & 48 & 1.41 \\
\hline Lepidophanes guentheri (Goode and Bean, 1896) & 74 & 693 & 41 & 808 & 23.81 \\
\hline Lobianchia gemellarii (Cocco, 1838) & 2 & & 1 & 3 & 0.09 \\
\hline Nannobrachium cuprarium Tåning, 1928 & 1 & 1 & & 2 & 0.06 \\
\hline Notolychnus valdiviae (Brauer, 1904) & 2 & 15 & 4 & 21 & 0.62 \\
\hline Notoscopelus sp. & & 6 & & 6 & 0.18 \\
\hline Total & 661 & 2363 & 370 & 3394 & 100 \\
\hline
\end{tabular}

Myctophid assemblages were not significantly different among the coastal, oceanic and seamounts stations $(\mathrm{p}=0.55)$. All Diaphus were collected outside the $1,000 \mathrm{~m}$ isobath, including some stations located over the seamounts (Fig. 8).
Lepidophanes guentheri and Myctophum larvae were widely distributed along the study area occurring from the continental shelf to the seamounts (Figs 9 and 10). Hygophum reinhardtii and Lampadena sp. were also widely distributed along the study 
Table III. Size range ( $\mathrm{mm} \mathrm{SL}$ ) and number of larvae collected during the three cruises, in each development stage.

\begin{tabular}{|c|c|c|c|c|c|}
\hline Species & Size range & Preflexion & Flexion & Postflexion & Postlarvae \\
\hline \multicolumn{6}{|l|}{ Myctophinae } \\
\hline Benthosema suborbitale & $3.5-24.5$ & 27 & 23 & 3 & \\
\hline Centrobranchus nigroocelatus & $4.4-6.5$ & 1 & 3 & & \\
\hline Diogenichthys atlanticus & $6.0-12.8$ & & 1 & & 1 \\
\hline Hygophum hygomii & $4.0-8.5$ & 3 & 4 & & \\
\hline Hygophum macrochir & $18.0-35.0$ & & & 1 & 1 \\
\hline Hygophum reinhardtii & $4.5-20.5$ & 86 & 19 & 27 & 2 \\
\hline Hygophum taaningi & $4.5-9.5$ & 1 & 1 & & \\
\hline Myctophum affine & $3.0-38.5$ & 31 & 11 & 9 & 7 \\
\hline Myctophum nitidulum & $3.5-26.5$ & 74 & 63 & 23 & 9 \\
\hline Myctophum obtusirostre & $3.2-52.0$ & 38 & 48 & 26 & 9 \\
\hline Myctophum selenops & $3.0-21.1$ & 44 & 31 & 29 & \\
\hline Symbolophorus rufinus & $7.0-10.0$ & 11 & 1 & 5 & \\
\hline \multicolumn{6}{|l|}{ Lampanyctinae } \\
\hline Bolinichthys photothorax & $15.3-30.5$ & & & 3 & \\
\hline Ceratoscopelus warmingii & $4.5-13.7$ & & 3 & 14 & \\
\hline Diaphus anderseni & 20.0 & & & & 1 \\
\hline Diaphus brachycephalus & $11.0-21.0$ & & & & 7 \\
\hline Diaphus dumerilii & $10.3-24.5$ & & & & 23 \\
\hline Diaphus garmani & $13.5-42.0$ & & & & 7 \\
\hline Diaphus splendidus & $11.2-44.0$ & & & & 47 \\
\hline Lampadena luminosa & 32.0 & & & & 3 \\
\hline Lampanyctus nobilis & 6.0 & & & 1 & \\
\hline Lepidophanes gaussi & $5.0-13.5$ & & 14 & 34 & \\
\hline Lepidophanes guentheri & $4.0-63.0$ & 14 & 190 & 291 & 313 \\
\hline Lobianchia gemellarii & $4.7-5.5$ & & 3 & & \\
\hline Nannobrachium cuprarium & $6.0-12.5$ & & & 2 & \\
\hline Notolychnus valdiviae & $11.0-21.0$ & & & & 21 \\
\hline Notoscopelus sp. & $3.4-5.0$ & 4 & & 2 & \\
\hline Total & & 334 & 415 & 470 & 451 \\
\hline
\end{tabular}

Table IV. Contribution percentage (90\%) of the most abundant taxa during the spring, winter and autumn for the average similarity, as determined by SIMPER. Taxa were listed according to its contribution for average similarity within each group.

\begin{tabular}{|c|c|c|c|c|c|}
\hline \multicolumn{2}{|c|}{ Spring } & \multicolumn{2}{|c|}{ Winter } & \multicolumn{2}{|c|}{ Autumn } \\
\hline H. reinhardtii & 30.4 & L. guentheri & 70.7 & H. reinhardtii & 39.6 \\
\hline M. nitidulum & 27.8 & Lampadena spp. & 14.7 & L. guentheri & 23.0 \\
\hline L. guentheri & 15.4 & H. reinhardtii & 6.1 & M. obtusirostre & 15.7 \\
\hline M. obtusirostre & 8.7 & & & Lampadena spp. & 14.0 \\
\hline M. selenops & 7.0 & & & & \\
\hline M. affine & 3.6 & & & & \\
\hline
\end{tabular}



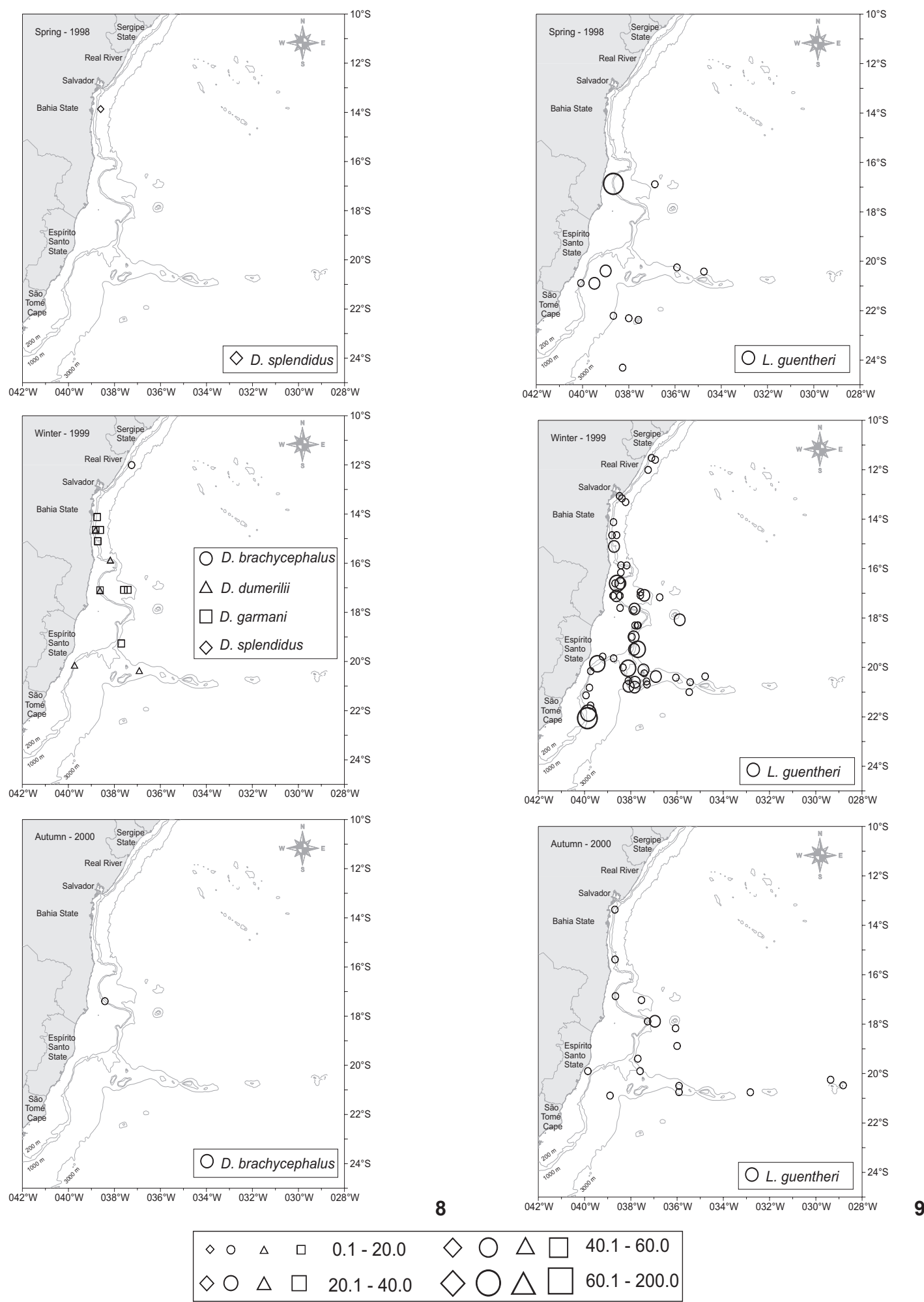

Figures 8-9. Density (larvae under $10 \mathrm{~m}^{-2}$ of sea surface) distribution of the most abundant myctophid species: Diaphus spp. (8), Lepidophanes guentheri (9).

ZOOLOGIA 27 (4): 541-553, August, 2010 


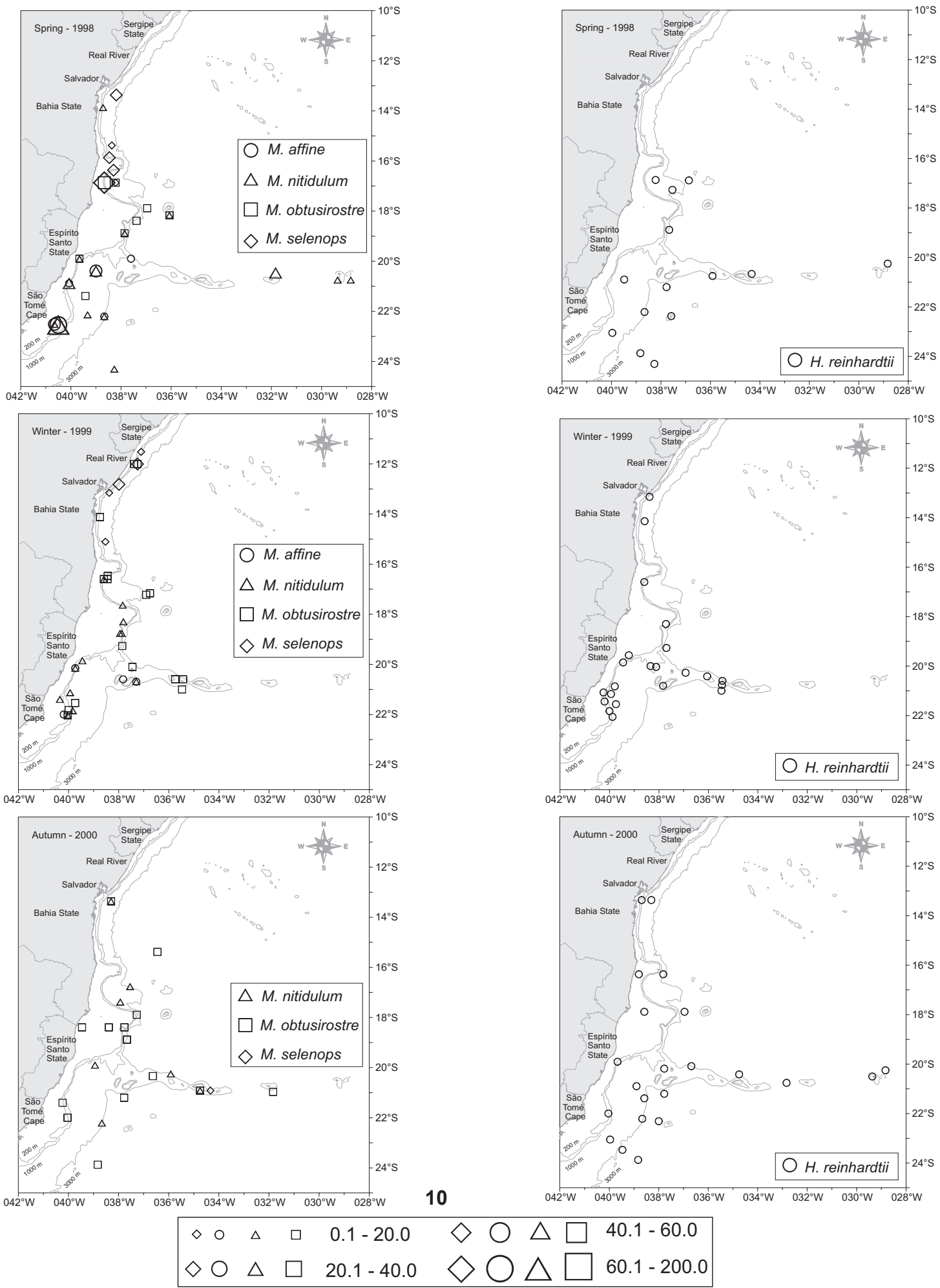

Figures 10-11. Density (larvae under $10 \mathrm{~m}^{-2}$ of sea surface) distribution of the most abundant myctophid species: (10) Myctophum spp.; (11) Hygophum reinhardtii . 

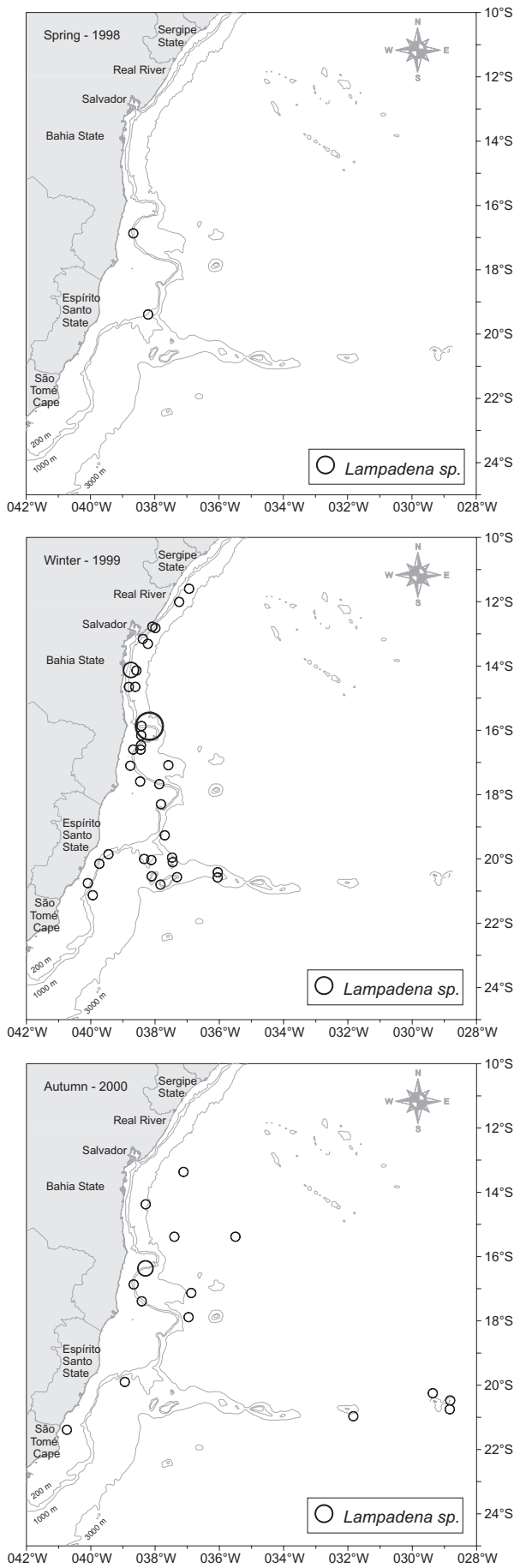

\begin{tabular}{|llllll}
$\diamond \diamond$ & $\Delta$ & $\square$ & $0.1-20.0$ & $\diamond \bigcirc \triangle \square$ & $40.1-60.0$ \\
$\diamond$ & $\triangle$ & $\square$ & $20.1-40.0$ & $\diamond \bigcirc \triangle \square$ & $60.1-200.0$ \\
\hline
\end{tabular}

Figure 12. Density (larvae under $10 \mathrm{~m}^{-2}$ of sea surface) distribution of the most abundant myctophid species: Lampadena sp. (12). area (Figs 11 and 12). Among the less abundant species, all occurred in samples collected in the oceanic region and over the seamounts. However, the species $C$. warmingii and $H$. taaningi were also collected in stations located over the continental shelf.

\section{Canonical Correspondence Analysis}

Monte Carlo global test showed a significant relationship in the environmental parameters used in correspondence analysis $(p=0.01)$. Correlations among environmental factors were low and the highest value recorded was between temperature and local depth (0.19). Salinity had low correlation with axes 1 and 2 and was not represented in figure 13 .

The species Lampanyctus sp., H. reinhardtii, Notolychnus valdiviae (Brauer, 1904) and Myctophum obtusirostre Tåning, 1928 were associated with greater depths and higher temperatures, while Lampadena sp., Diaphus splendidus (Brauer, 1904) and $M$. selenops were influenced by shallower depths and higher temperatures (Fig. 13). Myctophum affine, Lepidophanes gaussi (Brauer, 1906), Diaphus dumerilii (Bleeker, 1856) and L. guentheri were influenced by lower temperatures and shallower depths while B. suborbitale, M. nitidulum and S. rufinus were associated with lower temperatures and greater depths (Fig. 13).

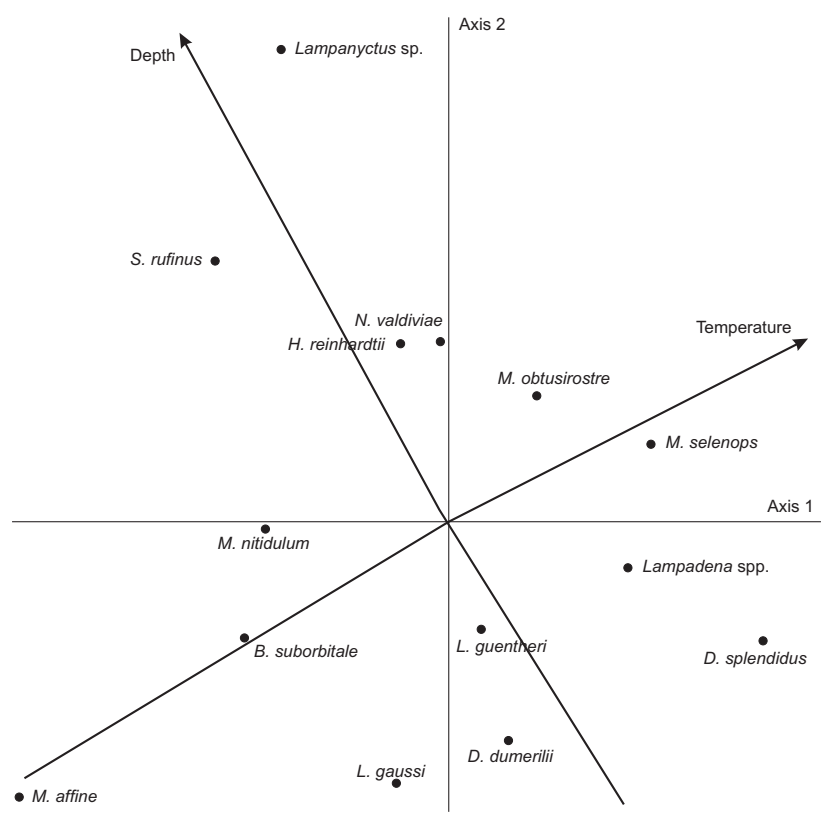

Figure 13. Canonical Correspondence Analysis between the most frequently collected myctophid taxa and environmental parameters (temperature at $20 \mathrm{~m}$ depth and local depth).

\section{DISCUSSION}

According to data obtained in this study and in the literature (Silveira et al. 2000) two water masses are dominant in this area: Tropical Water (TW) and South Atlantic Central Wa- 
ter (SACW). However, Shelf Water (SW) which is a mixture of TW and coastal water was also observed at some stations during the spring and the autumn. Temperature and salinity data obtained during this study were also analyzed by VALENTIN et al. (2007) and they verified that temperature varied vertically, decreasing towards greater depths, while salinity was more homogeneous within the water column. Temperatures below $20^{\circ} \mathrm{C}$ at $100 \mathrm{~m}$ depth observed near São Tomé Cape are evidence of SACW ascension during the three cruises. São Tomé Cape region is influenced by Cabo Frio upwelling system that is originated by the displacement of the Brazil Current off the continental shelf promoting the upwelling of SACW (VALENTIN et al. 2007). This region is also characterized by an increase of primary biomass (Сіотт et al. 2007) and depending of the season, there is an increase of zooplankton biomass and density (BONECKer et al. 2007b); an increase of primary biomass is also observed near Abrolhos Bank. Although an increase of larval fish densities in these areas was also expected, analyzing the density distribution of Myctophidae and other larval fish for the same area and period, one can assume that higher densities were more influenced by night samplings and by distance of the coast (BONECKER et al. 2007a). However, regarding our results for the most representative myctophids, there is an increase of L. guentheri, M. nitidulum and M. selenops densities near these two areas suggesting an association of these species with higher productivity. In a Hawaii study, Clarke (1973) found that the main spawning period for most myctophid species seems to be related to the seasonal peak in production of food.

Since many myctophid species have a circumglobal distribution (Hulley 1981, Gartener et al. 1989), some larvae collected in this study were also identified in other studies elsewhere in the world (Moser \& Ahlstrom 1970, Loeb 1979, Richards 1984, Ozawa 1986, Hulley 1992, Limouzy-Paris et al. 1994, Hulley \& Duhamel 1997, Sanvicente-AÑorve et al. 2000, Flores-Coto et al. 2000, Rodriguez et al. 2000, Marancink et al. 2005). Using the classification of faunal regions of the Atlantic Ocean (BACKUS et al. 1977), myctophids collected in this study occur in five different regions. The species H. hygomii and L. gaussi have a bipolar distribution; Diaphus anderseni Tåning, 1932, H. reinhardtii and $H$. taaningi occur in subtropical regions; $B$. suborbitale, C. warmingii, Diogenichthys atlanticus (Tåning, 1928), L. gemellari, M. nitidulum and $N$. valdiviae are recorded in tropical-subtropical areas; B. photothorax, D. brachycephalus and D. splendidus have a tropical-semisubtropical distribution; $D$. dumerilii, D. garmani, H. macrochir, L. guentheri, M. affine and M. obtusirostre occur in tropical regions. Hulley (1992) also separated the myctophid species that occurred in the oceanic zone (e.g. B. suborbitale, C. warmingii, M. nitidulum, M. selenops, $H$. hygomii, D. dumerilii, L. gemellarii) and in the pseudoceanic zone (e.g. D. garmani).

The distribution patterns of Myctophidae collected during the three oceanographic cruises were previously discussed in an identification guide from the Brazilian coast (CASTRO \&
BONECKER 2006) and are summarized below. There is no significant difference in the myctophid community considering a coastal-ocean gradient and most species are distributed widely in the study area, from Bahia coast $\left(12-18^{\circ}\right.$ S) to São Tomé Cape $\left(22^{\circ} \mathrm{S}\right)$, including the banks of Vitória-Trindade ridge $\left(21^{\circ} \mathrm{S}\right)$. However, D. anderseni, D. garmani, Hygophum species (except H. reinhardtii), B. photothorax, C. warmingii, Lampadena luminosa (Garmann, 1899), Lampanyctus nobilis Tåning, 1928, L. gemellari, Nannobrachium cuprarium Tåning, 1928, Notoscopelus sp., C. nigoocellatus and $D$. atlanticus were rare and restricted to small regions along the central coast. The restricted distribution of all but the two last species may be due to insufficient identification as many larvae were damaged or the pigment pattern was not preserved and specimens were identified only to genus or family level. Centrobranchus nigroocellatus and $D$. atlanticus specimens are easy to identify and were restricted to Espírito Santo coast, near Vitória and Davis banks $\left(20^{\circ} \mathrm{S}\right)$. Although the myctophid community seems to be similar in the coastal and oceanic environments, it varies significantly among seasons having a change in species dominance between winter and spring/autumn cruises. Seasonal differences in myctophid fauna were also observed between winter and summer off Eastern Australia and that author suggests that theses changes "may be mostly due to the natural seasonal cycles in individual species abundance" (BRANDT 1983). Hulley's (1992) study of the upper-slope distributions of myctophids found that "spatial and temporal variations in species distributions and abundance can occur in a small scale". A study developed along the CalCOFI domain attests that "long-term variability in abundance of oceanic species is strongly affected by climate" in this region, suggesting that some species can be useful in monitoring climate effects (Hsien et al. 2005). Another study done in the same area showed that abundances of oceanic species were strongly influenced by climate change (НsieH et al. 2009). Although all evidences that mesopelagic fishes distributions are strongly affected by temperature and climate changes it is important to say that in this study seasonal differences could also be influenced by sampling effort and period of the day. Donnelly \& TORREs (2008) found that seasonal changes in myctophid abundance were influenced by the trawling effort and by net avoidance during daytime samplings.

Some myctophid fauna studies report on changes in size composition in relation to seasonality and to different sampling depths. A study conducted in the northern Scotia Sea found that mean size of some myctophid species varied among five depth zones (Collins et al. 2008) and in Hawaii seasonal changes in size were quite pronounced (Clarke 1973). Although the present study did not analyze changes in size in relation to these two parameters, we found that older larvae were more abundant among the Lampanyctinae species, probably due to the greater number of younger larvae that were not identified to species (e.g. Diaphus spp. and Lampadena spp.). Normally, younger larvae are much more numerous than older ones, prob- 
ably because of net avoidance by larger larvae (Limouzy-PARIs et al. 1997) and natural mortality. In this study, a similar result was also observed for most Myctophinae species which were mostly preflexion stages.

Although adult myctophid identification is well studied around the world, little is known about species relationships with environmental parameters. Hulley (1981) studied the taxonomy and zoogeography of 124 myctophid species giving their distribution and some information of temperature limits. The association of $M$. selenops and N. valdiviae with warm waters that we obtained in this study was also found by Hulley (1981) who suggested that adult $M$. selenops distribution is associated with warm water gyre systems in the Atlantic Ocean. The association of B. suborbitale, M. affine, D. dumerilii and L. guentheri with low temperatures follows the results obtained by HulLeY (1981). Adults of B. suborbitale avoid warmer and more saline waters in its tropical distribution, and highest abundances of this species were recorded in temperatures between 15 and $17.5^{\circ} \mathrm{C}$ in the northern Sargasso Sea (Hulley 1981). Adults of $L$. guentheri have a shallower distribution at night and have a relationship with low temperatures $\left(15^{\circ} \mathrm{C}\right)$ at $200 \mathrm{~m}$ in the western North Atlantic (Hulley 1981). Myctophum affine distribution is limited to isotherm $15^{\circ} \mathrm{C}$ and $D$. dumerilii is absent from the minimum region of high temperature off Brazil, according to Hulley (1981). The same author attested that D. splendidus is limited to $18{ }^{\circ} \mathrm{C}$ and M. nitidulum is associated with warm water currents, but along the Brazilian coast the former species was related with warmer water while the later was more abundant in low temperatures.

The results obtained in this study has improved the knowledge of larval myctophid distribution along the Brazilian coast and showed the importance of seasonality in community composition. Although it also provided some evidence that temperature is an important factor for larval myctophid distribution, it is important to develop more accurate studies on distribution of this family in relation to physical parameters and to different water masses. With the impending development of oil fields off Brazil, data on the environment and fauna becomes imperative and this study provided important data that can be used in future experiments developed in the same region.

\section{ACKNOWLEDGMENTS}

The authors thank the team of Zooplankton and Ichthyoplankton Integrated Laboratory of Universidade Federal do Rio de Janeiro for assistance in field surveys. We also thank S.L.C. Bonecker for his comments on this manuscript and his help on data interpretation. Thanks to H.G. Moser for his help in larval identification and J.L. Valentin for his help with correspondence analysis. We thank M. Macedo for the artwork in ACC analysis. This study was supported by the Comitê Executivo, Comissão Interministerial para os Recursos do Mar (SECIRM), Ministério do Meio Ambiente (MMA), Plano Setorial para os Recursos do Mar. Additional support was provided by grant from
Coordenação de Aperfeiçoamento de Pessoal de Nível Superior (CAPES). Temperature and salinity data obtained during spring and autumn cruises were provided by Hydrobiology Laboratory of Universidade Federal do Rio de Janeiro.

\section{LITERATURE CITED}

Ahlstrom, E.H.; J.L. Butler \& B.Y. Sumida. 1976. Pelagic stromateoid fishes (Pisces, Perciformes) of the eastern Pacific: kinds, distributions, and early life histories and observations of five of these from the northwest Atlantic. Bulletin of Marine Science 26: 285-402.

Angel, M.V. 2003. The pelagic environment of the open ocean, p. 39-79. In: P.A. Tyler (Ed). Ecosystems of the World. Amsterdam, Elsevier, vol. 28, 582p.

Backus, R.H.; J.E. Craddock; R.L. Haedrich \& B.H. Robinson. 1977. Atlantic Mesopelagic Zoogeography, p. 266-287. In: R.H GIBBS JR (Ed.). Fishes of the Western North Atlantic. Memoir Sears Foundation for Marine Research 1 (Pt 7), 299p.

BECKER, V.E. 1983. Myctophidae of the world ocean. Moscow, Nauka, 248p.

Bonecker, A.C.T.; M.S. Castro; C. Namiki; F.T. Bonecker; F.B.A.G. Barros \& W.M. Monteiro-Ribas. 2007a. Ictioplâncton, p. 141159. In: J.L. VALENTIN (Ed.). Características hidrobiológicas da região central da Zona Econômica Exclusiva brasileira. Brasília, Ideal Gráfica e Editora, Série Documentos REVIZEE - Score Central, 168p.

Bonecker, S.L.C; C.O. Dias; L.D.A. Fernandes \& L.R.M. Ávila. 2007b. Zooplâncton, p. 125-140. In: J.L. VALENTIN (Ed.). Características hidrobiológicas da região central da Zona Econômica Exclusiva brasileira. Brasília, Ideal Gráfica e Editora, Série Documentos REVIZEE - Score Central, 168p.

Bonecker, S.L.C.; C.R. Nogueira; A.C.T. Bonecker; L.H.S. Santos; M.R. Reynier \& D.R. Tenenbaum. 1992/93. Estudo Hidrográfico e Planctonológico da Região entre Cabo Frio (Rio de Janeiro) e o Arquipélago de Abrolhos (BA). Nerítica 7 (1-2): 71-86.

BRANDT, S.B. 1983. Temporal and spatial patterns of lanternfish (family Myctophidae) communities associated with a warmcore eddy. Marine Biology 74: 231-244.

Castro, M.S. \& A.C.T. Bonecker. 2006. Myctophiformes. Myctophidae, p. 123-152. In: A.C.T. BONECKER \& M.S. CASTro (Eds). Atlas de larvas de peixes da região central da Zona Econômica Exclusiva brasileira. Rio de Janeiro, Museu Nacional, 214p.

Castro, B.M. \& L.B. Miranda. 1998. Physical oceanography of western Atlantic continental shelf located between $4^{\circ} \mathrm{N}$ and 34오 p. 209-251. In: R. Robinson \& K.H. Brink (Eds) The Sea. New York, John Wiley and Sons, vol. 11, 604p.

Ciotti, A.M.; E. Gonzalez-Rodriguez; L. Andrade; R. Paranhos \& W.F. Carvalho. 2007. Clorofila a, Medidas Bio-ópticas e Produtividade Primária, p. 61-72. In: J.L. Valentin (Ed.). Características hidrobiológicas da região central da Zona Econômica Exclusiva brasileira. Brasília, Ideal Gráfica e Editora, Série Documentos REVIZEE - Score Central, 168p. 
Clarke, T.A. 1973. Some aspects of the ecology of lanternfishes (Myctophidae) in the Pacific Ocean near Hawaii. Fishery Bulletin 71 (2): 401-434.

Clarke, K.R. \& R.M. Warwick. 1994. Change in marine communities: an approach to statistical analysis and interpretation. Plymouth, Natural Environmental Council, Plymouth Laboratories, 144p.

Collins, M.A.; J.C. Xavier; N.M. Johnston; A.W. North; P. Enderlein; G.A. Tarling; C.M. Waluda; E.J. Hawker \& N.J. Cunningham. 2008. Patterns in the distribution of myctophid fish in the northern Scotia Sea ecosystem. Polar Biology 31: 837-851.

Conley, W.J. \& T.L. Hopkins. 2004. Feeding ecology of lanternfish (Pisces: Myctophidae) larvae: prey preferences as a reflection of morphology. Bulletin of Marine Science. 75 (3): 361-379.

Costa, P.M. 2004. First record of Diaphus dumerilii (Myctophiformes: Myctophidae) off the Portuguese mainland coast. Journal of Fish Biology 64: 1435-1438.

Donnelly, J. \& J.J. Torres. 2008. Pelagic fishes in the Marguerite Bay region of the West Antartic Peninsula continental shelf. Deep-Sea Research II 55: 523-539.

Ekau, W. \& Y. MatsuUra. 1996. Diversity and distribution of ichthyoplankton in the continental shelf waters of East Brazil, p. 135-147. In: W. EkAU \& B. Knoppers (Eds). Sedimentation process and productivity in the continental shelf waters off East and Northeast Brazil. Joint Oceanographic Projects. JOPS II, Cruise Report and First Results. Bremen, Center for Tropical Marine Ecology, 151p.

Ekau, W.; P. Westhaus-Ekau \& C. Medeiros. 1999. Large scale distribution of fish larvae in the continental shelf waters off North-East Brazil. Archive of Fishery and Marine Research 47 (2/3): 183-200.

Emilson, I. 1959. Aspectos físicos e químicos das águas marinhas brasileiras. Ciência e Cultura 11 (2): 44-54.

Emilson, I. 1961. The shelf and coastal waters off southern Brazil. Boletim do Instituto Oceanográfico 11 (2): 101-112.

Flores-Coto, C.; F. Flores-Hernández; F. Zavala-Garcia; V. ArenasFuentes; M.A. Monreal-Gómez \& D.A. Salas-de-León. 2000. Oceanic and neritic icthyoplankton at the edge of the continental shelf in the Southern Gulf of Mexico. Gulf Caribbean Research 12: 31-35.

Gaeta, S.A.; J.A. Lorenzzetti; L.B. Miranda; S.M.M. Susini-Ribeiro; M. Pompeu \& C.E.S. Araújo. 1999. The Vitória eddy and its relation to the phytoplankton biomass and primary productivity during the austral fall of 1995. Archive of Fishery and Marine Research 47 (2/3): 253-270.

Gartner, J.V.; T.L. JR. Hopkins; R.C. Baird \& D.M. Milliken. 1987. The lanternfishes (Pisces: Myctophidae) of the eastern Gulf of Mexico. Fishery Bulletin 85: 81-98.

Gartner, J.V.; P. Steele \& J.J. Torres. 1989. Aspects of the distribution of lanternfishes (Pisces: Myctophidae) from the Northern Sargasso Sea. Bulletin of Marine Science 45: 555563.
Hsieh, C.; C. Reiss; W. Watson; M.J. Allen; J.R. Hunter; R.N. Lea; R.H. Rosenblatt; P.E. Smith \& G. Sugihara. 2005. A comparison of long-term trends and variability In populations of larvae of exploited and unexploited fishes in the Southern California region: A community approach. Progress in Oceanography 67: 160-185.

Hsieh, C.; H. Jinkim; W. Watson, E. Di Lorenzo \& G. Sugihara. 2009. Climate-driven changes in abundance and distribution of larvae of oceanic fishes in the southern California region. Global Change Biology 15: 2137-2151.

Hulley, P.A. 1981. Results of the research cruises of FRV "Walter Herwig" to South America. LVIII. Family Myctophidae (Osteichthyes. Myctophiformes). Archiv Fishereiwiss 31: 1-300.

Hulley, P.A. 1984. Myctophidae, p. 426-483. In: I.P.J.P. WHiteHEAD; M.L. Bauchot; J.C. Hureau; J. Nielsen \& E. Tortonese (Eds). Fishes of the north-eastern Atlantic and Mediterranean. Paris, Unesco, 1473p.

Hulley, P.A. 1986. Myctophiformes, p. 282-322 In: M.M. SмiтH \& P.C. Heemtra (Eds). Smith's sea fishes. Johannesburg, Macmillan South Africa, 1047p.

Hulley, P.A. 1992. Upper-slope distributions of oceanic lanternfishes (family: Myctophidae). Marine Biology 114: 365-383.

Hulley, P.A. 1994. Lanternfishes, p. 127-128. In: M. Paxton \& W.N. EschmeYer (Eds). Encyclopedia of Fishes. San Diego, Academic Press, 240p.

Hulley, P.A. \& G. Duhamel. 1997. Lanternfishes (Myctophidae) collected during the 1971-PELAGIA cruises of R.V. "Coriolis" in the south-west Pacific Ocean. Cymbium 21 (3): 299-317.

KarakulaK, F.S.; A. Salman \& I.K. Oray. 2009. Diet composition of bluefin tuna (Thunnus thynnus L. 1758) in the Eastern Mediterranean Sea, Turkey. Journal of Applied Ichthyology 25: 757-761.

Limouzy-Paris, C.B.; M.F. Mcgowan; W.J. Richards; J.P. Umaran \& S.S. CHA. 1994. Diversity of fish larvae in the Florida Keys: results from SEFCAR. Bulletin of Marine Science 54 (3): 857-870.

Limouzy-Paris, C.B.; H.C. Graber; D.L. Jones; A.W. Röpke \& W.J. RichaRDS. 1997. Translocation of larval coral reef fishes via sub-mesoscale spin-off eddies from the Florida Current. Bulletin of Marine Science 60: 966-983.

Lовв, V.J. 1979. Vertical distribution and development of larval fishes in the North Pacific Central Gyre during summer. Fishery Bulletin 77 (4): 777-793.

Marancik, K.E.; L.M. Clough; J.A. Hare. 2005. Cross-shelf and seasonal variation in larval fish assemblages on the southeast United States continental shelf off the coast of Georgia. Fishery Bulletin 103: 108-129.

Mc Cune, B. \& M.J. Mefrord. 1999. PC-ORD. Multivariate Analysis of Ecological Data, Version 4. Gleneden Beach, MJM Software Design, 237p.

Moser, H.G. \& E.H. Ahlstrom. 1970. Development of lanternfishes (family Myctophidae) in the California 
Current. Part I. Species with narrow-eyed larvae. Los Angeles, Bulletin of the Los Angeles County, Museum of Natural History Science 7, 145p.

Moser, H.G. \& E.H. Анцstrom. 1974. Role of larval stages in systematic investigations of marine teleostes: the Myctophidae. a case study. Fishery Bulletin 72 (2): 391-413.

Moser, H.G. \& E.H. АнLstrom. 1996. Myctophidae: Lanternfishes, p. 387-475. In: H.G. Moser (Ed.). The Early Stages of Fishes in the California Current Region. La Jolla, Calcofi Atlas (33), 1505p.

Moser, H.G.; E.H. Ahlstrom \& J.R. Paxton. 1984. Myctophidae: Development, p. 218-239. In: H.G. Moser; W.J. Richards; D.M. Cohen; M.P. Fahay; A.W. Kendall Jr. \& S.L. Richardson (Eds). Ontogeny and systematics of fishes. La Jolla, American Society of Ichythyologist and Herpetologist Special Publication (1), 759p.

Moser, H.G. \& W. Watson. 2006. Myctophidae: Lanternfishes, p. 473-579. In: W.J. Richards (Ed.). Early Stages of Atlantic Fishes: an Identification Guide for the Western North Atlantic. Boca Raton, CISC Press, , vol. 1, 2640p.

Nafpaktitis, B.G. 1975. Review of the lanternfish genus Notoscopelus (Family Myctophidae) in the North Atlantic and the Mediterranean. Bulletin of Marine Science 25: 75-87.

Nafpaktitis, B.G.; R.H. Backus; J.E. CRaddock; R.L. Haedrich; B.H. Robinson \& C. Karnella. 1977. Family Myctophidae, p. 13265. In: R.H. GibBs JR (Ed). Fishes of the Western North Atlantic. Lawrence, Memoir Sears Foundation for Marine Research, 1 (Pt. 7), 299p.

Nelson, J.R. 2006. Fishes of the World. Hoboken John Wiley and Sons, $4^{\text {th }}$ ed., 601p.

Nogueira, C.R.; L.H.S. SAntos; A C.T. Bonecker; S.L.C. Bonecker; C.O. Dias \& J.M.L. Reis. 1999. Studies on Zooplankton and Ichthyoplankton Communities off the Rio de Janeiro Coastline, p. 73-98. In: S.H.G. Silva \& H.L. Lavrado (Eds). Ecologia dos Ambientes Costeiros do Estado do Rio de
Janeiro. Rio de Janeiro, Oecologia Brasiliensis, vol. 7, 304p. Nonaka, R.H.; Y. Matsuura \& K. Suzuki. 2000. Seasonal variation in larval fish assemblages in relation to oceanographic conditions in the Abrolhos Bank region off eastern Brazil. Fishery Bulletin 98: 767-784.

Olivar, M.P. \& I. Palomera. 1994. Ontogeny and distribution of Hygophum benoiti (Pisces. Myctophidae) of the North Western Mediterranean. Journal of Plankton Research 16 (8): 977-991.

Ozawa, T. 1986. Early life history of the family Myctophidae in the ocean off southern Japan, p. 114-188. In: T. OzAwA (Ed.) Studies on the oceanic ichthyoplankton in the western North Pacific. Fukuoka, Kyushu University Press, 430p.

RichaRds, W.J. 1984. Kinds and abundance of fish larvae in the Caribbean Sea and adjacent areas. Seattle, NOAA Technical Report NMFS SSRF-776, 54p.

RodrígueZ, J.M.; J.G. Braun \& A. Garcia. 2000. Spatial variability of the mesozooplankton biomass and ichthyoplankton in the Canary region, in autumn 1991. Journal of Plankton Research 22 (7): 1377-1391.

Sanvicente-Añorve, L.; C. Flores-Coto \& X. Chiappa-Carrara. 2000. Temporal and spatial scales of ichthyoplankton distribution in the Southern Gulf of Mexico. Estuarine, Coastal and Shelf Science 51: 463-475.

Silveira, I.C.A.; A.C.K. SchmidT; E.J.D. Campos; S.S. Godor \& Y. IKEDA. 2000. A corrente do Brasil ao largo da costa leste brasileira. Revista Brasileira de Oceanografia 48: 171-183.

Valentin, J.L.; R. Paranhos; B.C.M.T. Faro \& A.S.M. Gonzalez. 2007. Massas d'Água, p. 21-29. In: J.L. VAlentin (Ed.). Características hidrobiológicas da região central da Zona Econômica Exclusiva brasileira. Brasília, Ideal Gráfica e Editora, Série Documentos REVIZEE - Score Central, 168p.

Zelck, C.; H.-C. John \& M.P. Olivar. 1993. The larval development of Symbolophorus rufinus (Tåning. 1928) (Teleostei. Myctophidae). Mitteilungen aus dem Hamburgischen Zoologischen Museum und Institut 90: 313-320.

Submitted: 13.III.2009; Accepted: 26.V.2010.

Editorial responsibility: Antonio Ostrensky 